СОТНИК В. О., к. т. н., старший викладач кафедри автоматики та комп'ютерного телекерування рухом поїздів,

БОЙНИК А. Б., д. т. н., професор

(Український державний університет залізничного транспорту)

\title{
Вплив професійної підготовки кадрів у господарстві автоматики та телекомунікацій щодо забезпечення перевізного процесу
}

У иүій статті розглянуто проблему дефіuиту кадрів основних професій у господарстві автоматики та телекомунікацій $і$ його вплив на забезпечення безпеки руху поӥздів. На основі аналізу чисельності контингенту масових професій, обсягу виконуваних робіт та продуктивності прачі визначено вплив зменшення кількості прачівників на якість технічного обслуговування пристроїв автоматики та зв'язку і забезпечення безпеки руху. Автори дійшли висновку, щуо зменшення чисельності працівників у господарстві автоматики та телекомунікацій на сьогоднішній день істотно не вплинуло на забезпечення безпеки руху поӥздів. Проте невідповідність між розрахунковими показниками кількості працівників основних професій $i$ їх плановими значеннями негативно впливає на роботу господарства. Ця проблема мало вивчена $і$ потребує подальших досліджень.

Ключові слова: кадри основних професій, автоматика та зв'язок, обсяг виконуваних робіт, продуктивність праці, нормативи чисельності, знос технічних засобів, технічна оснащеність, безпека руху, професійна підготовка кадрів.

\section{Вступ}

Актуальність теми статті пояснюється тим, що останніми роками все більш гостро постає питання дефіциту кадрів основних професій у господарстві сигналізації та зв'язку Укрзалізниці [1-4]. Тому необхідно виконати аналіз та зробити оцінку стану справ із забезпеченням безпеки руху поїздів i дотриманням технології виконання робіт. Такій аналіз доцільно провести залежно від наявності кадрів основних провідних професій та динаміки зміни чисельності персоналу господарства автоматики та телекомунікацій АТ «УЗ». При цьому обов'язково враховувати динаміку зміни оснащення дистанцій сигналізації та зв'язку.

\footnotetext{
Основний матеріал та методи дослідження

Аналіз контингенту господарства сигналізації та зв'язку

Контингент господарства розраховується залежно від обсягу виконуваної роботи 3 обслуговування та ремонту пристроїв СЦБ та зв'язку, тому розглянемо зміну обсягу робіт у період з 2012 по 2020 роки (рис. 1).

За вказаний період найбільший обсяг робіт був у 2012 році (38496,8 техн. одиниць), протягом 2013 2014 pр. він змінився не суттєво. Починаючи 3 2014 року обсяг виконуваних робіт зменшився, і вже у 2016 році склав 33133,3 техн. одиниці [3]. В
}

(C) В. О. Сотник, А. Б. Бойник, 2021 подальшому ситуація 3 технічним оснащенням стабілізувалась і обсяг робіт практично не змінювався до нинішнього часу.

Незважаючи на зміни обсягу виконуваних робіт, продуктивність праці за розглядуваний період зросла на $23 \%$ (рис. 2).

У 2012 році продуктивність праці становила 1,95 техн.од./люд, а вже у 2020 році - 2,4 техн.од./люд. При цьому слід зазначити, що підвищення продуктивності праці обумовлена не змінами обсягу виконуваних робіт і чисельності штату, а перекосами в плануванні, які були закладені із самого початку. До такого стану призвела відсутність реальних технічно обгрунтованих нормативів чисельності персоналу господарства, пов'язаного з експлуатацією, ремонтом та будівництвом пристроїв СЦБ та зв'язку (фактичний контингент майже у 2 рази менший за розрахунковий, визначений нормативами чисельності працівників господарства, затверджених наказом від 26.07.2004 № 594-Ц3. 


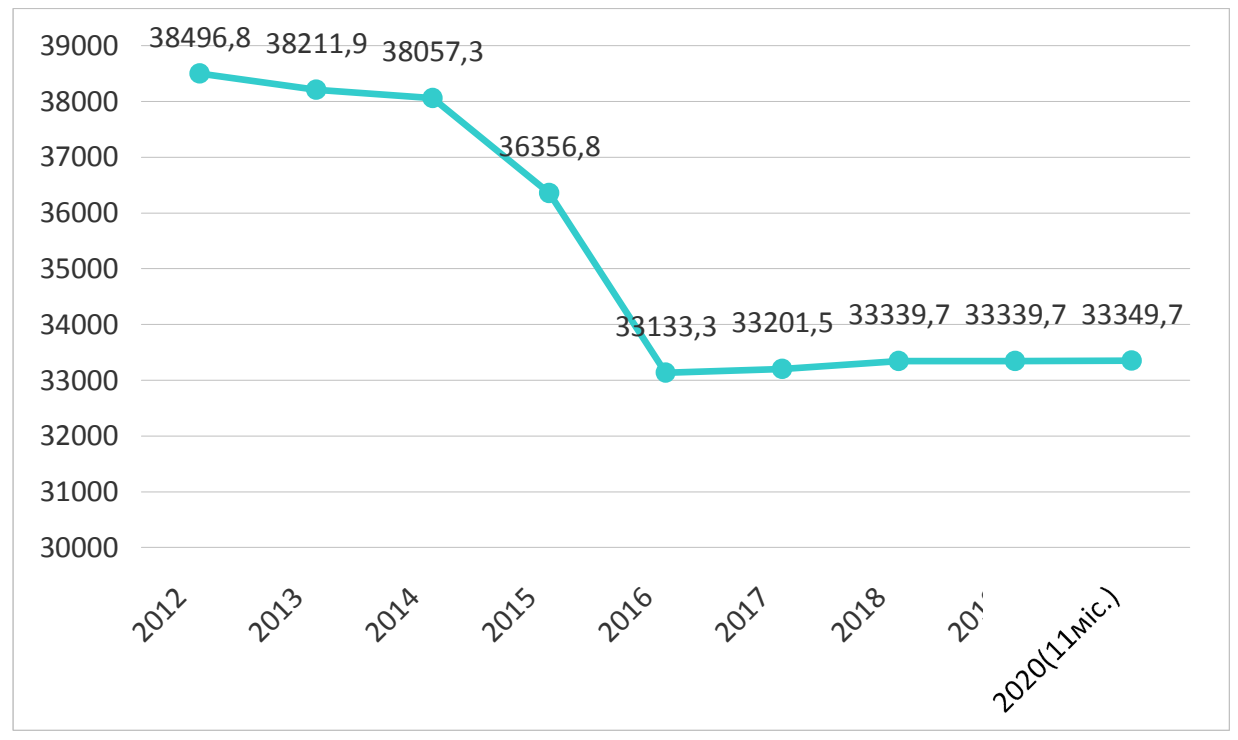

Рис. 1. Обсяг робіт у господарстві автоматики та телекомунікацій Укрзалізниці за період 2012 - 2020 рр. (техн. одиниць)

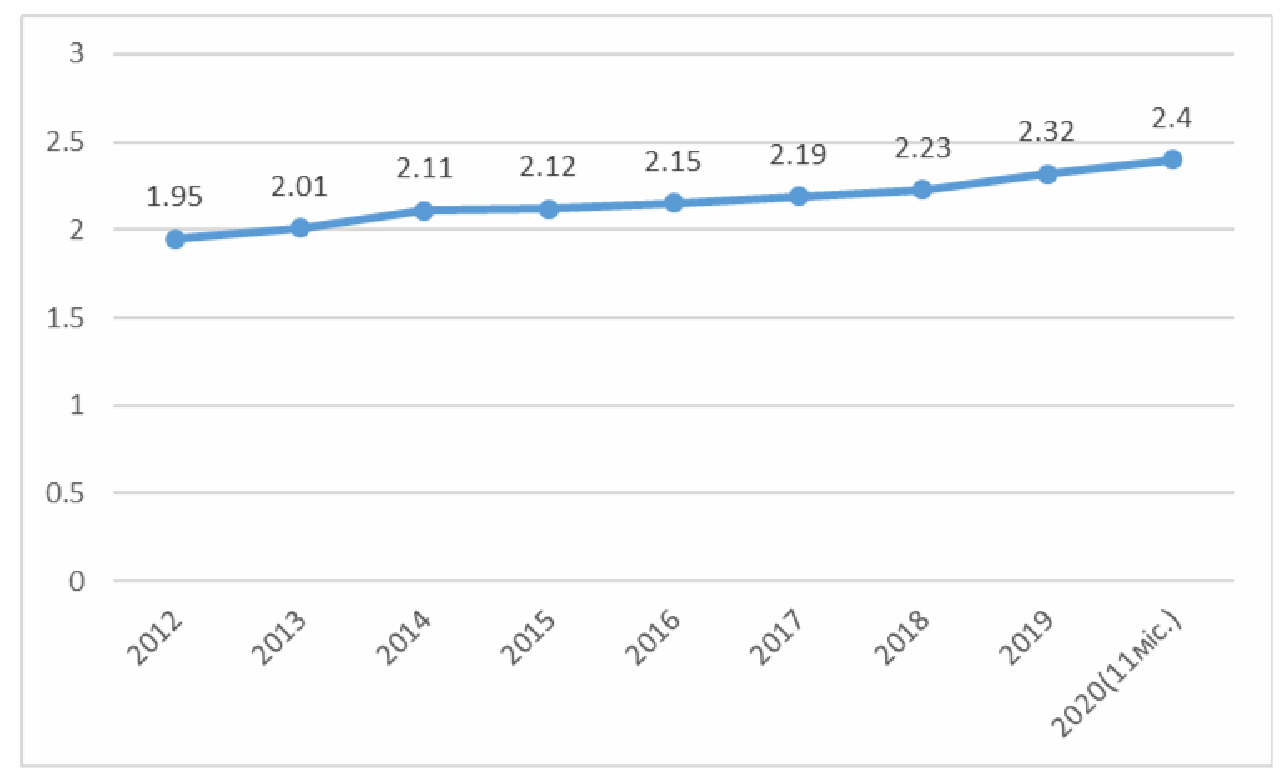

Рис. 2. Продуктивність праці в господарстві автоматики та телекомунікацій Укрзалізниці за період 2012-2020 рр. (техн.од./люд)

Слід зазначити, що розрахункова чисельність $є$ у прямій залежності від обсягу виконуваних робіт, а також від особливостей графіків технологічних процесів і періодичності виконання робіт. 3 цього випливає, що дане планування середньоспискової чисельності призвело до того, що виконання графіків технологічних процесів має проводитись 3 інтенсивністю, що у два рази перевищує заплановану. В таких умовах експлуатаційний штат вимушений зменшувати розрахунковий час на виконання однієї операції з обслуговування пристроїв, а це, як звісно, призводить до погіршення якості обслуговування пристроїв.

Слід зауважити, що найбільший контингент основних професій складають електромеханіки СЦБ, на що вказує аналіз (рис. 3), тому доцільно виконати оцінку зменшення штату інших професій у порівнянні до зменшення штату електромеханіків СЦБ [5]. 


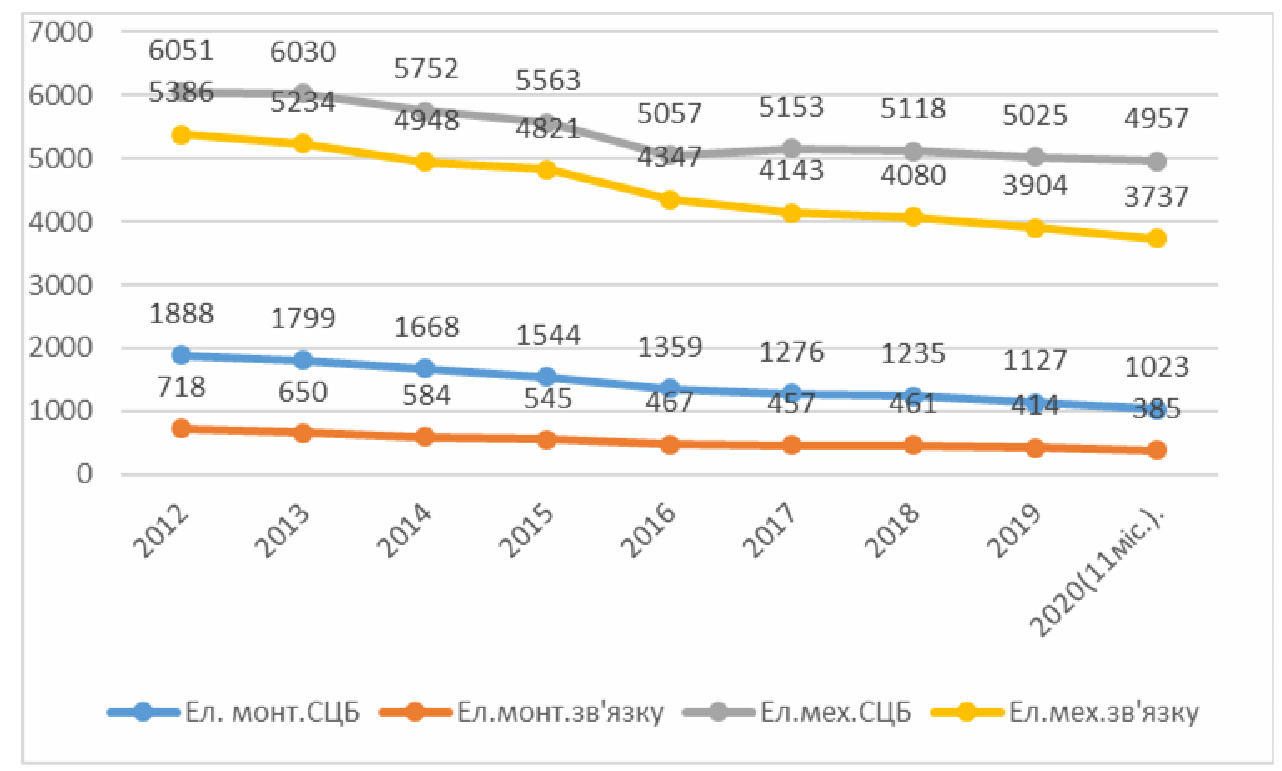

Рис. 3. Середньоспискова чисельність контингенту основних професій у господарстві автоматики та телекомунікацій Укрзалізниці за період 2012-2020 рр.

Динаміка зміни чисельності основних професій у період 32012 по 2020 роки.

Зміни чисельності штату основних професій [5] у розглянутому періоді наведено в табл. 1.

Таблиця 1

\begin{tabular}{|c|c|c|c|c|}
\hline Роки & $\begin{array}{c}\text { ШН } \\
\text { СЦБ }\end{array}$ & $\begin{array}{c}\text { ШН } \\
\text { Зв'язку }\end{array}$ & $\begin{array}{c}\text { ШМ } \\
\text { СЦБ }\end{array}$ & $\begin{array}{c}\text { ШМ } \\
\text { зв'язку }\end{array}$ \\
\hline 2012 & 6051 & 5386 & 1888 & 718 \\
\hline 2013 & 6030 & 5234 & 1799 & 660 \\
\hline 2014 & 5752 & 4948 & 1668 & 584 \\
\hline 2015 & 5563 & 4821 & 1544 & 545 \\
\hline 2016 & 5057 & 4347 & 1359 & 467 \\
\hline 2017 & 5044 & 4143 & 1276 & 457 \\
\hline 2018 & 5118 & 4080 & 1235 & 461 \\
\hline 2019 & 5025 & 3904 & 1127 & 414 \\
\hline $\begin{array}{c}2020 \\
(11 \text { міс.) }\end{array}$ & 4916 & 3737 & 1023 & 392 \\
\hline
\end{tabular}

Таким чином, якщо прийняти наявність контингенту основних професій 2012 року за базову (100\%), то динаміку іiі зміни протягом 2012 - 2020 рp. можна оцінити за допомогою виразу:

Кз.ш.=Шн.п./Шк.п.х100 \%,

де Кз.ш. - коефіцієнт зменшення штату, \%;

Шн.п. - штат початкового періоду, люд;

Шк.п. - штат кінцевого періоду.

Результати розрахунків зведено в табл. 2.
Таблиця 2

\begin{tabular}{|l|c|c|c|}
\hline \multicolumn{1}{|c|}{ Професії } & $\begin{array}{c}\text { Чисельність } \\
2012 \text { р., люд }\end{array}$ & $\begin{array}{c}\text { Чисельність } \\
2020 \text { р., люд }\end{array}$ & $\begin{array}{c}\text { Кз.ш., } \\
\%\end{array}$ \\
\hline $\begin{array}{l}\text { Ел. механіки } \\
\text { СЦБ }\end{array}$ & 6051 & 4916 & 81 \\
\hline $\begin{array}{l}\text { Ел. механіки } \\
\text { зв'язку }\end{array}$ & 5386 & 3737 & 69 \\
\hline $\begin{array}{l}\text { Ел. монтери } \\
\text { СЦБ }\end{array}$ & 1888 & 1023 & 54 \\
\hline $\begin{array}{l}\text { Ел. монтери } \\
\text { зв'язку }\end{array}$ & 718 & 382 & 53 \\
\hline
\end{tabular}

Аналіз даних табл. 2 свідчить, що протягом розглянутого періоду кількість електромеханіків СЦБ зменшилась на $19 \%$, електромеханіків зв'язку - на $31 \%$, електромонтерів СЦБ - на $46 \%$, а електромонтерів зв'язку - на $47 \%$. Такі відсотки зменшення штату основних професій не відповідають динаміці змін технічної оснащеності (обсягу робіт) у господарстві за період з 2012 по 2020 роки.

Аналіз зносу технічних засобів господарства автоматики та телекомунікацій

Наступним фактором, який впливає на обсяг виконуваних робіт 3 обслуговування пристроїв, а також на якість роботи та безвідмовність цих пристроїв, є їх знос. Аналіз даних діаграми зносу основних засобів СЦБ та зв'язку за період з 2012 по 2020 роки свідчить про те, що найбільший відсоток прийшовся на 2013 - 2015 роки. Починаючи 3 2016 року внаслідок проведеної модернізації знос зменшується. У 2016 році він уже складає 43,8 \%. 3 
цього ж року зменшується і технічна оснащеність господарства. У 2014 році вона складала 38057,3 техн. одиниці, у 2016 році вона склала 33133,3 техн. одиниці, тобто зменшилась на $13 \%$ (рис. 4). В цей самий період відбувається i зменшення штату основних професій.

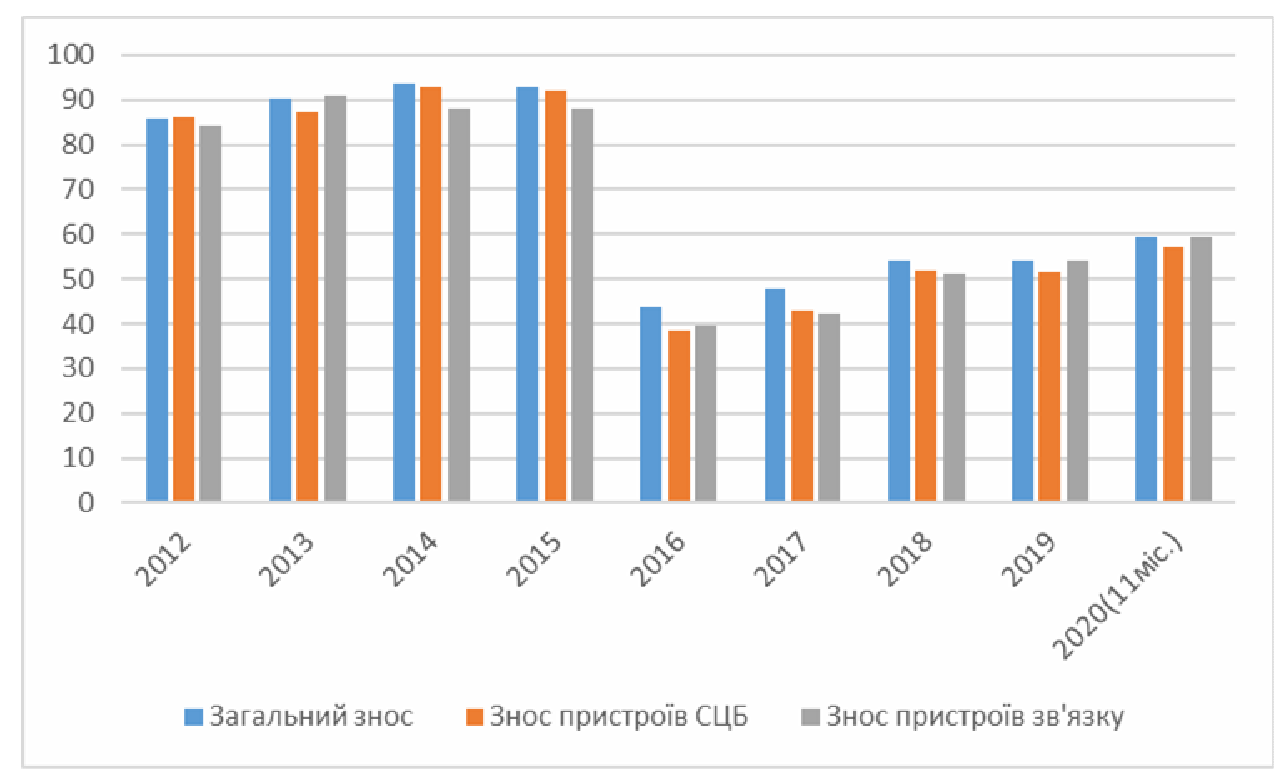

Рис. 4. Знос основних засобів СЦБ та зв’ язку Укрзалізниці за період 2012-2020 рр.

Порівняльний аналіз зменшення контингенту i технічного оснащення свідчить про те, що:

- зміни обсягів робіт у господарстві приводили до змін у чисельності контингенту основних професій, але динаміка змін контингенту не відповідала динаміці змін технічної оснащеності господарства;

- знос основних засобів господарства вдалося значно зменшити починаючи з 2016 року. При цьому слід зазначити, що вже з 2017 року і до сьогодні він знову зростає;

- продуктивність праці в господарстві автоматики та телекомунікацій у розглянутий час при змінах обсягів виконуваних робіт практично не змінювалась. При цьому слід зазначити, що вона складала і складає в окремі періоди понад двох технічних одиниць на людину. Це відбулося, як уже було вказано раніше, за рахунок неправильного планування середньоспискової чисельності штату без урахування розрахункового показника [6, 7].

Аналіз зміни чисельності контингенту основних професій i іï вплив на якість обслуговування пристроїв

Критерієм оцінки якості обслуговування пристроїв $\epsilon$ їх надійна ї безвідмовна робота, тобто кількість відмов, які призвели до тих або інших наслідків.

Загальна кількість відмов пристроїв СЦБ протягом розглянутого періоду, беручи до уваги [4], змінювалась таким чином (рис. 5).
Найбільша кількість відмов була у 2012 році (1543 відмови), у 2014 році вона зменшилась на $23 \%$ i склала 1191 відмову. Це стало можливим тому, що в цей період було проведено заміну застарілих пристроїв СЦБ та зв'язку на пристрої 3 новою елементною базою. Таким чином розподілились і відмови, викликані порушенням технології виконання робіт.

Відмови пристроїв 3 невиявлених причин слід розглянути окремо. Цей показник найбільш яскраво висвітлює ступінь технічних знань і професійної підготовки експлуатаційного персоналу (рис. 6).

Аналіз даних рис. 6 свідчить, що відмови 3 невиявлених причин, незважаючи на зміни загальної кількості відмов, практично є незмінними протягом усього розглянутого періоду.

Незважаючи на значний відплив саме професійних кадрів господарства, той запас, який був накопичений у попередні роки, ще достатній для забезпечення стабільної роботи господарства. 


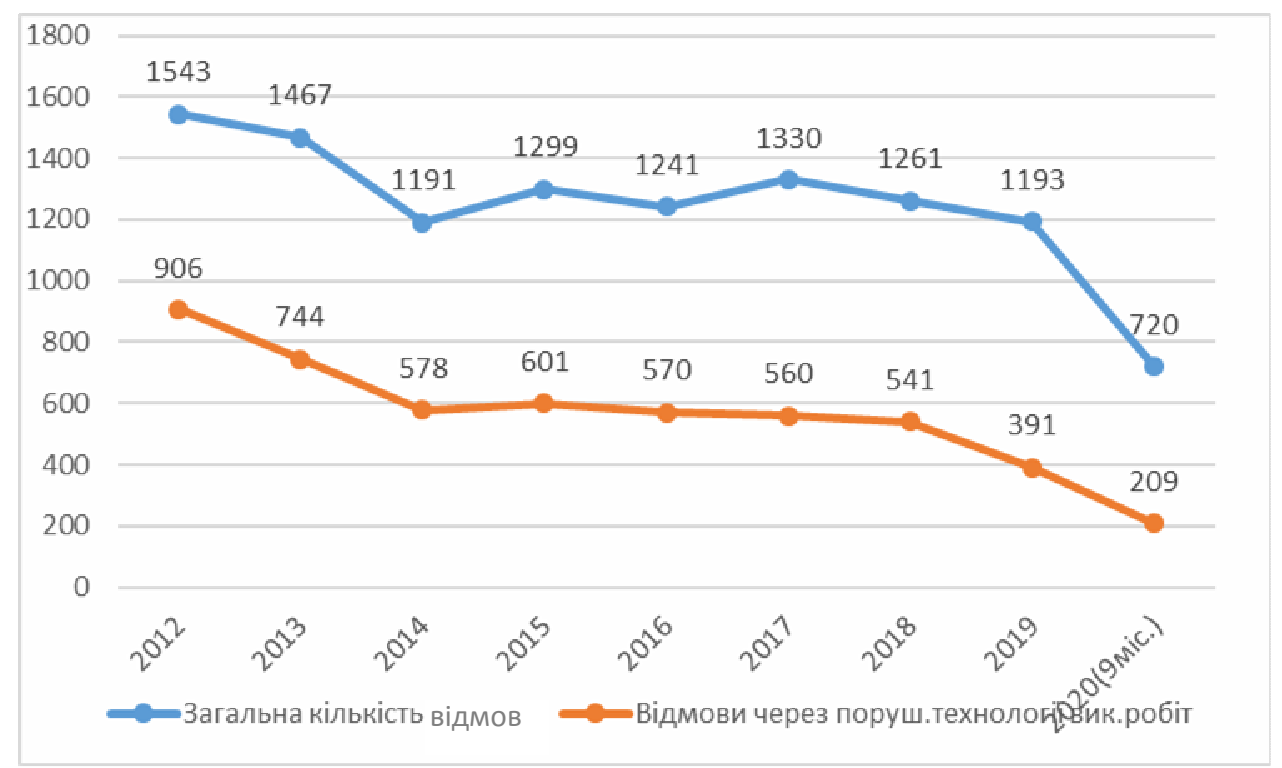

Рис. 5. Кількість відмов пристроїв СЦБ через порушення технології виконання робіт Укрзалізниці за період 2012-2020 pp.

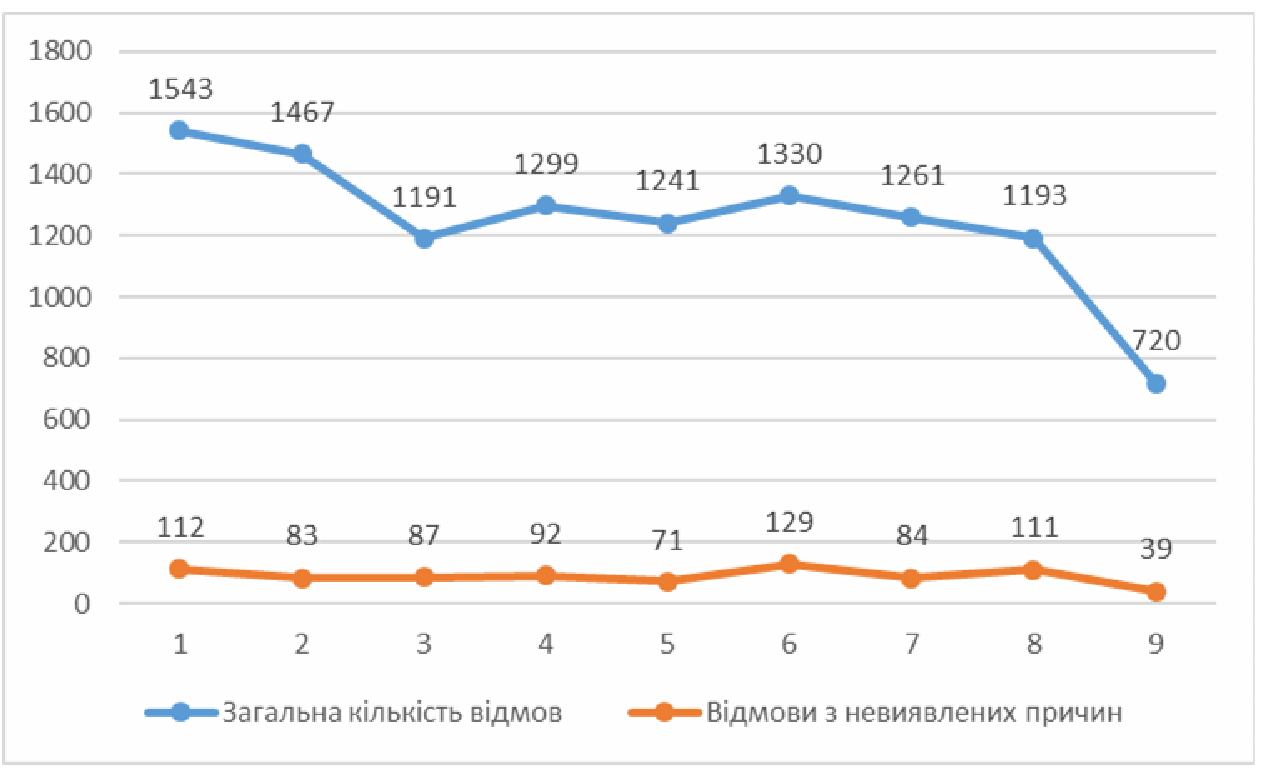

Рис. 6. Кількість відмов пристроїв СЦБ з невиявлених причин в Укрзалізниці за період 2012-2020 pp.

\section{Висновки}

1. За розглянутий період господарству автоматики та телекомунікацій вдалося забезпечити стабільну і якісну роботу пристроїв СЦБ та зв'язку. Проведено модернізацію пристроїв, яка позитивно вплинула на їх роботу.

2. Скорочення штату працівників господарства автоматики та телекомунікацій суттєво не вплинуло на стан забезпечення безпеки руху поїздів. Але при цьому слід зазначити, що невідповідність між розрахунковими показниками контингенту i ïx плановими показниками негативно впливають на роботу господарства.

3. Необхідно приділити увагу професійній підготовці працівників господарства, особливо масових професій. Аналізуючи приплив фахівців у господарство із вищих та професійно-технічних закладів освіти, слід зазначити, що їх кількість 3 кожним роком зменшується. Заповнення професійними кадрами стає все більш проблемним. У цих умовах необхідно особливу увагу приділити професійній підготовці вже працюючих фахівців. 
Особливо це стосується кадрів лінійних станцій, де через дефіцит місцевих фахівців доводиться використовувати професійно не підготовлених працівників.

4. Система технічного навчання в дистанціях сигналізації та зв'язку є малоефективною. Водночас через недостатню укомплектованість студентами викладацький штат вищих i професійно-технічних закладів освіти в повній мірі не завантажений. Тому необхідно розглянути можливість організувати професійне навчання спеціалістів безпосередньо на підприємствах господарства, 3 оформленням договірних відносин між закладами освіти і Укрзалізницею, що дасть змогу навчати працівників безпосередньо у виробничому процесі. Крім того, за результатами такого навчання необхідно надати можливість комісійного присвоєння відповідної кваліфікації безпосередньо на підприємстві. Таким чином, це дозволить не тільки підняти рівень професійної підготовки фахівців, а й вирішити питання 3 кадровим дефіцитом таких професій, як електромеханіки СЦБ та зв'язку і електромонтери СЦБ та зв'язку.

\section{Список використаних джерел}

1. Інструкція з забезпечення безпеки руху поїздів при виконанні робіт з технічного обслуговування та ремонту пристроїв СЦБ на залізницях України: ЦШЕОТ-0018. Київ, 1999.

2. Інструкція з технічного обслуговування пристроїв СЦБ: ЦШ-0060. Київ, 2009.

3. Інструкція 3 організації системи технічного обслуговування пристроїв провідного зв'язку на залізничному транспорті. - ЦШ-0051. Київ, 2007.

4. Довідки про виробничо-фінансову діяльність по господарству сигналізації та зв'язку регіональних філій АТ «Укрзалізниця» за період з 2012 по 2020 роки.

5. Аналіз стану безпеки руху в структурі Укрзалізниці за 2012 - 2020 роки. Розроблено Департаментом безпеки руху Укрзалізниці.

6. Диагностирование устройств железнодорожной автоматики и агрегатов подвижных единиц / А. Б. Бойник, Г. И. Загарий, С. В. Кошевой, Н. И. Луханин, И. В. Поэта. Харьков: ЧП изд-во «Новое слово», 2008. 304 с.

7. Самсонкин В. Н., Бойник А. Б., Прогонный А. Н. К вопросу эффективного управления работой дистанций сигнализации и связи. Електромагнітна сумістність та безпека на залізничному транспорті. 2018. № 16. С. 95 - 105.
Сотник В. А., Бойник А. Б. Влияние профессиональной подготовки кадров в хозяйстве автоматики и телекоммуникаций относительно обеспечения перевозочного процесса.

Аннотация. В настоящей статье рассматривается проблема дефицита кадров основных профессий в хозяйстве автоматики и телекоммуникаций и его влияние на обеспечение безопасности движения поездов. На основе анализа численности контингента массовых профессий, объема выполняемых работ и производительности труда определено влияние уменьшения количества работников на качество технического обслуживания устройств автоматики и связи и обеспечение безопасности движения. Авторы приходят к выводу, что уменьшение численности работников в хозяйстве автоматики и телекоммуникаций в настоящее время существенно не повлияло на обеспечение безопасности движения поездов. Однако несоответствие между расчетными показателями количества работников основных профессий и их плановыми значениями негативно влияет на работу хозяйства. Эта проблема мало изучена и требует дальнейших исследований.

Ключевые слова: кадры основных профессий, автоматика и связь, объём выполняемых работ, производительность труда, нормативы численности, износ технических средств, техническая оснащённость, безопасность движения, профессиональная подготовка кадров.

Sotnik V. A., Boinik A. B. The influence of professional training of personnel in the economy of automation and telecommunications in relation to the provision of the transportation process.

Abstract. This article examines the problem of the shortage of personnel in the main professions in the economy of automation and telecommunications and its impact on ensuring the safety of train traffic. Based on the analysis of the number of mass occupations, the volume of work performed and labor productivity, the influence of a decrease in the number of employees on the quality of maintenance of automation and communication devices and ensuring traffic safety was determined. The authors come to the conclusion that the decrease in the number of employees in the automation and telecommunications economy has not significantly influenced the provision of train traffic safety at the present time. However, the discrepancy between the calculated indicators of the number of workers in the main professions and their planned values negatively affects the operation of the economy. This problem has been little studied and requires further research.

Key words: personnel of basic professions, automation and communications, volume of work performed, labor 
productivity, headcount standards, wear and tear of technical means, technical equipment, traffic safety, professional training of personnel.

Надійшла 24.02.2021 p.

Сотник Василь Олександрович, кандидат технічних наук, старший викладач кафедри автоматики та комп'ютерного телекерування рухом поїдів, Український державний університет залізничного транспорту, Харків, Україна. E-mail: sotnyk.va@gmail.com ID ORCID: https://orcid.org/0000-0002-8039-1392

Бойник Анатолій Борисович, доктор технічних наук, професор, завідувач кафедри автоматики та комп'ютерного телекерування рухом поїзів, Украӥнський державний університет залізничного транспорту, Харків, Украӥна. E-mail: at@kart.edu.иа ID ORCID: https://orcid.org/0000-0001-7773-9055

Vasily Aleksandrovich Sotnyk, Candidate of Technical Sciences, Senior Lecturer of the Department of automatic and computer remote control of train traffic, Ukrainian State University of Railway Transport, Kharkiv, Ukraine. E-mail: sotnyk.va@gmail.com ID ORCID: https://orcid.org/0000-0002-8039-1392

Boynik Anatoly Borisovich, Dr.Sc., professor, chief of department of automatic and computer remote control of train traffic, Ukrainian State University of Railway Transport, Kharkiv, Ukraine. E-mail: at@kart.edu.ua ID ORCID: https://orcid.org/0000-0001-7773-9055 